\title{
Strengthening Psychological Capital as an Important Element of Sustainable Employee Development in the Context of Requirements and Resources in the Workplace
}

\author{
Agnieszka Wojtczuk-Turek \\ Institute of Human Capital, Collegium of Business Administration, \\ SGH Warsaw School of Economics
}

\begin{abstract}
The article discusses the issue of strengthening psychological capital as an element of sustainable employee development. Psychological capital (PsychCap), consisting of effectiveness, optimism, hope, and resilience is an important element of employees' subjective resources, which may contribute to effective completion of professional tasks and high levels of engagement, and at the level of subjective effects - psychological well-being. Activities aimed at developing particular components of PsychCap in the organisation may be carried out as part of specially planned, organised and systematically conducted interventions, coaching, as well as meetings of the manager with his/her subordinate team.
\end{abstract}


Keywords: psychological capital, sustainable development, requirements and resources at work JEL Classification Code: M12

\section{Introduction}

The use of the sustainable development concept in the analysis of the functioning of enterprises allows for the transformation of the perception of their goals and success, as well as responsibility towards stakeholders. A sustainable organisation aims to provide economic, social and environmental benefits at the same time. The implementation of this concept in the area of human capital management draws attention to the need to achieve not only the economic objectives of the company, but also to satisfy and balance the needs of its employees. Sustainable human resource management (Ehnert \& Harry, 2012; Cohen, Taylor, \& Muller-Camen, 2012) supports the strategy of sustainable development of the organisation, puts an emphasis on fair treatment, cares for the development and health of employees, supports environmentally friendly organisational practices, promotes work-life balance, assumes the development of employees' competence and psychological well-being (sometimes treated as a synonym of happiness). The latter aspect fits in with the concept of positive psychology (Seligman et al., 2005) and positive organisational behaviour (Luthans, 2002). In line with these assumptions, the analysis focuses on the capabilities and abilities of the individual and the interest in how psychological resources and positive attitudes of employees can influence the sense of well-being and results in the workplace (Luthans, 2002). This is particularly important in the light of changes in work practices and constantly increasing demands that may disturb work-life balance.

The purpose of the article is to review empirical research on psychological capital - a specific individual resource, and analysis of the possibility of its strengthening in the organisation as an element of sustainable development of employees. The review was based on conducting literature studies.

\section{Requirements versus resources in the workplace}

When characterising occupational requirements, one should pay attention to the key attributes of work in Industry 4.0. Its dominant feature is the wide use of technology and various applications of artificial intelligence, as well as automation and robotisation of professional activities, present in many sectors of the economy. Consequences related to technology and ubiquitous computer infrastructure are also 
reflected in a broader context, because, as the authors emphasise, the integration of the physical and electronic space affects the organisation of work processes, privacy, security, and finally, it creates new business models (Cascio \& Montealegre, 2016). Researchers point out that new technologies make it possible to coordinate operations in different locations, and in order to ensure competitive advantage of the company, they speed up decision-making processes and shorten production cycles by adapting them to the needs of its customers. Meeting the requirements is connected with the need to increase work efficiency and implement more flexible organisational structures, as well as implementation of a number of practices including, among others, employment reduction, outsourcing, or decentralisation (Kubicek \& Korunka, 2017).

Not only do technologies help to achieve tasks faster and better, but they also influence changes in the way work is done, related to the ability to communicate in a continuous manner (Cascio \& Montealegre, 2016). Mobile devices offering the possibility of constant online contact or unlimited access to data in the network and digital knowledge resources make job performance independent of the place of employment (and working time), and thus creating new opportunities. At the same time, this situation poses some threats, e.g. 'forcing' unrestricted availability of employees and extending the time of completing professional tasks beyond the scope of designated hours, occurrence of information overload, as well as enforcement of changes in behaviour in the face of the need for adaptation and lack of matching between man and work (in the context of work requirements and resources) (Wojtczuk-Turek, 2019). The most striking change with regard to work is its intensification, which means that more tasks have to be carried out during the day and in a shorter time, as well as increasing the variety of tasks to be completed (Kubicek \& Korunka, 2017).

The job demands-resources theory is a useful theoretical framework for describing employees' behaviours and attitudes, as well as the results they achieve in the context of working conditions (Job Demands-Resources Theory - JD-R) (Bakker \& Demerouti, 2007, 2017). This model groups the factors that occur in the working environment into two categories: requirements and resources. It also allows for determining how both types of factors affect the well-being of the individual and his or her functioning at work.

Requirements are defined as physical, psychological, social and organisational aspects of work that require physical or psychological effort (Bakker \& Demerouti, 2007). Requirements, regardless of their nature, involve an employee putting effort into coping with them, resulting in emotional, cognitive and physical costs that can lead to exhaustion. Referring to this model while analysing the intensification of work, Kubicek and Korunka (2017) point out that intensification means a need for 
labour requiring constant effort and, although it may lead to higher productivity in a short period of time, the effects on workers are generally negative.

In the face of increasing requirements, employees take on different strategies to deal with such a situation. Active coping means increased efforts to achieve higher performance targets, which, in turn, results in physical strain (and thus increased physiological parameters such as increased heart rate, increased blood pressure, or increased adrenaline secretion) and generates psychological costs (fatigue) (Kubicek \& Korunka, 2017). While this method of coping is useful for a short-term increase in demand for labour since it enables productivity objectives to be achieved by increasing labour input, in the long term it can lead to work overload.

Other negative consequences include physical health problems, higher levels of emotional exhaustion and lower levels of work engagement, as well as imbalances in personal and professional life. These negative effects may be reduced by the employee's resources. Within the meaning of the JD-R theory, resources come down to physical, psychological, social or organisational. They are beneficial for the achievement of individuals' professional goals, reduce the level and importance of work requirements, and stimulate personal development and learning (Bakker \& Demerouti, 2007).

Resources can be divided into: 1) organisational, e.g. HRM practices; 2) interpersonal relations, e.g. atmosphere in a team; 3) position, e.g. participation in decision-making; 4) tasks, e.g. differentiation of tasks (Bakker \& Demerouti, 2007).

From the point of view of job resources, which can help individuals cope with emotional needs and demands at work (e.g. work in services), the authors mention job autonomy, social support, climate of authenticity and psychosocial safety climate (Boyd et al., 2015). They correspond to individual resources, considered within the scope of expanding the range of factors included in the conceptualisation of the JD-R theory. They include optimism and self-efficacy (Baker \& Demerouti, 2018), which, together with hope and resilience, form the so-called psychological capital (Luthans, Youssef, \& Avolio, 2007). Its analysis and development among employees seems to be important in the context of new circumstances, indicated by researchers, which define the ways of professional functioning - namely that coping with new requirements concerning work that are currently observed may be more dependent on individual factors than it was previously the case (Kubicek \& Korunka, 2017). Especially since the information and emotional overload of employees, high expectations in terms of productivity and the increasing intensity of work are the daily "landscape of the working environment' in many organisations. 


\section{Psychological capital as a resource of employees generating beneficial effects and welfare in the face of workplace requirements}

One of the ways of conceptualising the subjective resources of an individual in the workplace is psychological capital - PsychCap (Sweetman \& Luthans, 2010; Youssef \& Luthans, 2013). It is a positive psychological state of development of the individual, characterised by: 1 ) the belief in the ability to make and continue the effort necessary to succeed in difficult tasks (self-efficacy), 2) positive reference to the possibility of succeeding now and in the future (optimism), 3) persistent pursuit of goals and a change in the way they are achieved (when necessary) with confidence in success (hope), 4) ability to survive and recover even when problems and obstacles in achieving success arise (resilience) (Luthans, Youssef, \& Avolio, 2007, p. 3). Based on this description, it can be concluded that psychological capital is a configuration of motivational and behavioural tendencies derived from four components: self-efficacy, optimism, hope, and resilience. All the components create the so-called positive psychological resources (Youssef \& Luthans, 2013; Luthans et al., 2015) and are relevant in terms of professional activity (WojtczukTurek, 2014). The resulting acronym HERO (standing for hope, efficacy, resilience, optimism) metaphorically illustrates their 'causal power', and at the same time, as stated by Youssef and Luthans (2013), they best meet the criteria for inclusion in positive organisational behaviours (they must be positive, based on theory and evidence, measurable, open to development) (Youssef-Morgan \& Dahms, 2017). According to the authors, these resources should be treated as a representative set, although it does not exhaust the taxonomy which includes other psychological constructs, such as the cognitive resources of creativity and wisdom, or emotional resources (Youssef \& Luthans, 2013).

In respect to management in organisations, it is important that the components constituting the psychological capital of the employee can be measured, developed and effectively managed in order to improve the effectiveness of the organisation (Wojtczuk-Turek, 2014). It can be referred to through the prism of psychological capital relations with various types of organisational and individual factors. Research shows clearly its relationship with performance (Avey, Nimnicht, \& Pigeon, 2010), commitment (Sweetman \& Luthans, 2010), leadership (Caza et al., 2010). At the level of subjective effects, relationships with satisfaction (Luthans et al., 2007), trust (Walumbwa et al., 2011), psychological well-being (Youssef \& Luthans, 2013) have been established. 
For a deeper description and understanding of the effects of having positive psychological resources in the context of workplace requirements and psychological well-being, it is worth analysing their mechanisms. Among the most important mechanisms explaining the impact of PsychCap on the individual's sense of wellbeing one can mention (Youssef \& Luthans, 2013) cognitive, affective, and social ones. Their short description is presented in Table 1.

\section{Table 1. Description of selected mechanisms explaining the impact of PsychCap on} well-being

\begin{tabular}{|l|l|}
\hline $\begin{array}{l}\text { Cognitive } \\
\text { mechanisms }\end{array}$ & $\begin{array}{l}\text { As Youssef and Luthans (2013) point out, PsychCap components directly influence } \\
\text { the interpretation of a given situation, which in turn determines an individual's } \\
\text { sense of well-being. It results from a positive assessment of both current activities } \\
\text { and future expectations of success. Positive subjective assessments are a stronger } \\
\text { predictor of well-being than objective events. A beneficial effect of positive } \\
\text { evaluation of the situation is the treatment of undesirable or difficult tasks in the } \\
\text { categories of challenges which can mobilise and reduce psychological costs of their } \\
\text { implementation. It also encourages an active search for resources needed for work. }\end{array}$ \\
\hline $\begin{array}{l}\text { Affective } \\
\text { mechanisms }\end{array}$ & $\begin{array}{l}\text { Since PsychCap is associated with positive emotions (Youssef \& Luthans, 2013), } \\
\text { its contribution to generating a sense of well-being seems obvious. The authors } \\
\text { explain the affective processes by referring to the Broaden-and-Build Model of } \\
\text { B. Fredrickson (2009). According to the model, experiencing long-term positive } \\
\text { emotions at work and less negative emotions leads to building up psychological } \\
\text { and social resources by individuals, which translates not only into their well- } \\
\text { being but also helps to meet requirements. In this sense, the model allows us } \\
\text { to understand the role of PsychCap in triggering and sustaining positive emotions, } \\
\text { and to regulate and focus our actions on a greater number of goals, aspirations, } \\
\text { which in turn can contribute to the positive affect. }\end{array}$ \\
\hline $\begin{array}{l}\text { Social } \\
\text { mechanisms }\end{array}$ & $\begin{array}{l}\text { Psychological capital is not only a mediator between supportive social climate and } \\
\text { productivity at work, but through social learning mechanisms and persuasion } \\
\text { it is a mechanism for building effectiveness, and social support is identified as } \\
\text { a key factor in maintaining resilience (Youssef \& Luthans, 2013). In turn, positive } \\
\text { relations and social support may contribute to strengthening the components of } \\
\text { capital. Furthermore, a positive assessment of workplace relationships can make } \\
\text { them more meaningful and promote a sense of psychological well-being. }\end{array}$ \\
\hline
\end{tabular}

Source: study based on Youssef \& Luthans (2013).

The mechanisms of influence of psychological capital on psychological well-being of employees described above explain at the same time the ways of coping with the requirements in the workplace. The function of positive psychological resources of an individual is manifested in self-regulation and self-motivation. At the cognitive level, the feeling of causation and self-efficacy (Bandura, 2007) is a key element of motivation and determines taking action, the effort put into it, the feelings that accompany it, perseverance in reaching one's goal, and coping with obstacles 
and failures. It also influences the mobilisation of cognitive resources necessary to perform tasks. Its positive effects on the professional functioning of employees are reflected, for example, in job crafting. These actions consist of - according to the conceptualisation of this construct within the resource requirement model by Tims, Bakker and Derks (2012) - four types of actions: 1) increasing structural resources, 2) increasing social resources, 3) increasing challenging requirements, 4) reducing requirements constituting impediments. These activities contribute not only to a better match between man and work, but also to professional satisfaction and the sense of meaning of their job. Moreover, employees who, through a sense of selfefficacy assess the probability of success as high are proactive, take on additional tasks and actively transform their work, and this is conducive to meeting needs and developing skills (Tims, Bakker, \& Derks, 2014). Meta-analyses of research on the relationship between job crafting behaviours and subjective and organisational factors show that generalised belief in effectiveness is linked to job shaping by mediating (impacting?) outcomes at the level of attitudes, professional well-being and productivity (Rudolph et al. 2017).

From the perspective of the high requirement of creativity in the workplace, present in jobs where work is characterised by a high degree of intensity and knowledge saturation, all the resources constituting PsychCap seem to be important. Self-efficacy, optimism and hope are important for taking up behaviours in order to create changes in the environment (proactive) and modify modes of action in order to better adapt to changes in the environment (reactive). On the other hand, mental resilience determines the continuation of activity despite changes in the environment.

Taking into account the implementation of creative challenges in the workplace, one should point out the role of a specific kind of conviction concerning the possibility of undertaking creative activities (sense of creative self-efficacy) (Tierney \& Farmer, 2002). Studies confirm that psychological capital combined with individual flexibility allows for predicting the readiness of employees to manifest innovative behaviours in the workplace, and it is especially enhanced by the belief in their own effectiveness and hope (Wojtczuk-Turek \& Turek, 2015). In the context of workplace functioning and performance, it is also worth mentioning the so-called 'professional selfefficacy', which is a predictor of psychosocial well-being and plays an important role in the perception of challenges (e.g. mental overload) and obstructive requirements (e.g. lack of control and social support). A high level of professional self-efficacy is associated with the perception of more challenges and fewer obstacles, which, in turn, results in an increased engagement and lower risk of burn-out (Ventura, Salanova, \& Llorens, 2015).

Emotional work requirements generating high overloads may reduce another type of psychological resource - mental resilience. Its possession by an individual 
allows for acting efficiently when faced with difficult tasks or relationships that are a source of mental discomfort. One way of dealing with emotional demands in the workplace is to reduce the factors that cause them. However, transforming work towards eliminating burdensome challenges (which are the source of negative emotions) is avoidance rather than problem-solving, and therefore, is not positively perceived by superiors. The constructive role of resilience is expressed in balancing the negative effects of stressors in the workplace and allows for target-oriented activity.

In the context of the failures experienced as a result of a challenge that could not be met, it is also necessary to mention optimism. Described in the theory of attribution, it combines the style of interpretation (Seligman, 1988). Perceiving failures as temporary events of limited scope and relating its causes to external factors ensures that an individual does not lose the incentive to act. In addition to the motivating function, optimism is a kind of activity regulator; thanks to selective perception (focusing attention on the positive aspects of a task), the individual continues to carry out various tasks and brings them to a successful conclusion.

To sum up, it can be stated that positive psychological resources have a direct impact on professional functioning - by performing the functions of self-regulation, self-motivation, and goal achievement by employees, which contributes to both task performance and contextual performance.

\section{Strengthening psychological capital in the organisation as an element of sustainable development of employees}

Developing psychological capital helps to increase employees' self-confidence, thereby addressing challenges and coping effectively with obstacles and difficulties, thus contributing to increasing productivity and other psychological resources. From the perspective of managers, for whom the most important task is to stimulate employee engagement in order to achieve business goals, strengthening the psychological capital of employees may prove to be crucial. Considering the fact that engagement is a cognitive-effective state (Schaufeli, Bakker, \& Salanova, 2006), a positive perception of circumstances and individual abilities (being the essence of psychological capital) may improve motivation to make efforts aimed at organisational goals. An indirect mechanism through which PsychCap leads to work engagement are positive emotions (Sweetman \& Luthans, 2010).

Organisational psychological capital can be developed through organised, intentional activities as well as informal situations that provide an opportunity to strengthen psychological resources. The former include micro-interventions, 
about which Luthans wrote together with his associates (Luthans et al., 2006). Special organised sessions lasting from 1 to 3 hours included:

- as regards developing hope - designing goals, generating paths and overcoming obstacles;

- strengthening optimism by anticipating negative events and related potential obstacles, and then creating alternative pathways to minimise their impact;

- in terms of building effectiveness stemming from task mastery - enabling experience and modelling success, and through persuasion and stimulation of the pursuit of personal goals set at the beginning of the session. This is also helped by imaginative experience in mastering tasks;

- as part of increasing resilience - impact on its components: asset factors, risk factors and influence processes. The most effective strategies are based on increasing assets and proactively avoiding risky, potentially adverse events.

The effectiveness of the discussed interventions in the development of particular components of PsychCap has been confirmed empirically in research conducted in a quasi-experimental model (Luthans et al., 2010). On this basis, it was possible to determine the impact of these interventions on productivity at work.

To carry out activities similar to those used in the described interventions, organisations may undertake coaching. It is largely based on modifying - within the coach-coachee relationship - thought patterns influencing the interpretation of various situations and shaping the image of one's own person. And while coaching goals are specific and usually related to the professional context (it is different only in life coaching), their achievement is often preceded by modifying the assumptions and beliefs that an individual has. In addition, the process involves using resources and raising their awareness, which contributes to the development of employees. The studies confirmed quasi-experimentally that participation in coaching contributes to changes in the range of expected results and increases the effectiveness in formulating goals (Evers, Brouwers, \& Tomic, 2006). Other effects resulting from the use of cognitive behavioural techniques include an increase in selfesteem (Libri \& Kemp, 2006) and self-confidence (Kambarakaran et al., 2008), which is related to self-efficacy.

Developing positive resources can also be part of management activities, carried out as part of meetings with employees or organisational practices known as 'performance management'. They can be used to diagnose problems, set objectives, develop solutions, and, in the context of developing PsychCap, assess the impact in terms of the implementation of tasks, level of control, and capacity to undertake various actions. Using cognitive processes to reduce setbacks and broaden employee behavioural control helps to build the sense of agency, resilience and realistic optimism in the face of job requirements. An important element of these activities is also the 
assistance of one's superior in solving problems related to challenges. It generates the effects that Luthans et al. (2006) wrote about: the process of counteracting pessimism supports the development of realistic but optimistic expectations and is enhanced by positive conversation (Luthans et al., 2006).

While broadening the scope of activities that can be used to support psychological capital, the role of HRM practices should be mentioned. The study on the relationship between these activities and self-efficacy showed that people with a low level of selfefficacy see greater importance of HRM practices in stimulating their productive behaviours (Wojtczuk-Turek, 2016). Apart from professional skills needed to perform job-related tasks, the obtained effect may justify the fact of including in the scope of development of employees' competences also strengthening positive psychological resources within the framework of one of the most important personal practices - training and professional development. This will be in line with the idea of sustainable employee development.

\section{Conclusion and future research}

The article discusses the issue of strengthening psychological capital as an element of sustainable employee development. Psychological capital (PsychCap), which consists of effectiveness, optimism, hope, and resilience, is an important element of employees' subjective resources, which may contribute to effective completion of professional tasks and high levels of engagement and, at the level of subjective effects, psychological well-being.The conducted review of studies on psychological capital indicates a number of positive effects to which the application of this concept leads in the context of professional functioning of employees, described in the article. This justifies reinforcing it in employees. Effective ways for development of PsychCap in the organisational dimension include organised measures, which comprise specially designed interventions directed at increasing hope, optimism, selfefficacy, and resilience. They may form an element of training influence planning.

Other measures include coaching (as well as mentoring), but also specific managerial practices. Naturally, there is still room for more measures for implementation, and therefore, new research areas within the field of PsychCap reinforcement, and recommendations for management practices are emerging.

One of interesting directions for analyses related to the development of PsychCap is job crafting, forming a manifestation of proactivity in the workplace. Further to the fact that it is based on increasing social and structural resources, as well as challenges, encouraging employees to modify their work may give them an opportunity to increase their personal resources, which form the components of psychological 
capital. Achieving aims related to gaining resources and shaping relationships in the workplace, provides employees with a chance to gain new competences and increase effectiveness of their activities, which, in turn, facilitates the increase of PsychCap.

\section{References}

Avey, J.B., Nimnicht, J.L., \& Pigeon, N.G. (2010). Two field studies examining the association between positive psychological capital and employee performance. Leadership \& Organization Development Journal, 31(5), 384-401.

Bakker, A.B., \& Demerouti, E. (2007). The Job Demands-Resources model: State of the art. Journal of Managerial Psychology, 22, 309-328.

Bakker, A.B., \& Demerouti, E. (2017). The Job Demands-Resources theory: Taking and looking forward. Journal of Occupational Health Psychology, 22(3), 273-285.

Bakker, A.B., \& Demerouti, E. (2018). Multiple levels in job demands-resources theory: Implications for employee well-being and performance. In: E. Diener, S. Oishi, L. Tay, (Eds.), Handbook of wellbeing. Salt Lake City, UT: DEF Publishers, 1-13.

Bandura, A. (2007). Much ado over a faulty conception of perceived self-efficacy grounded in faulty experimentation. Journal of Social and Clinical Psychology, 26(6), 641-658.

Boyd, C.M., Hayward, R.M., Tuckey, M.R., Dollard, M.F., \& Dormann, Ch.H. (2015). Emotion work in service occupations. Links to well-being and job performance. In: M. Van Veldhoven, R. Peddei (Eds.), Well-being and Performance at Work. The Role of Context, New York: Psychology Press, 55-74.

Cascio, W.F., \& Montealegre, R. (2016). How Technology Is Changing Work and Organization. Annual Review of Organizational Psychology and Organizational Behavior, 3, 349-375.

Caza, A., Bagozzi, R.P., Woolley, L., Levy, L., \& Caza B.B. (2010). Psychological capital and authentic leadership. Measurement, gender, and cultural extension. Asia-Pacific Journal of Business Administration, 2(1), 53-70.

Evers, W.J.G., Brouwers, A., \& Tomic, W. (2006). A Quasi-experimental Study on Management Coaching Effectiveness. Consulting Psychology Journal: Practice and Research, 58(3), 174-182.

Fredrickson, B.L. (2009). Positivity. New York: Crown/Random House.

Libri, V., \& Kemp, T. (2006). Assessing the efficacy of a cognitive behaviour executive coaching programme. International Coaching Psychology Review, 1(2), 9-18.

Kombarakaran, F.A., Yang, L.A., Baker, M.N., \& Fernandes, P. (2008). Executive coaching: itworks! Consultant Psychology Journal: Practice and Research, 60(1), 78-90.

Kubicek, B., \& Korunka, Ch. (2017). Job demands in a changing world of work. In: R.J. Burke, K.M. Page (Eds.), Research Handbook on Work and Well-Being, Cheltenham: Edward Elgar Publishing, 
Luthans, F. (2002). Positive organizational behavior: Developing and managing psychological strengths. Academy of Management Executive, 16, 57-72.

Luthans, F., Avey, J.B., Avolio, B.J., Norman, S.M., \& Combs, G.M. (2006). Psychological capital development: toward a micro-intervention. Journal of Organizational Behaviour, 27, 387-393.

Luthans, F., Youssef, C.M., \& Avolio, B.J. (2007). Psychological capital: Developing the human competitive Edge. Oxford: Oxford University Press.

Luthans, F., Avolio, B.J., Avey, J.B., \& Norman, S.M. (2007). Positive psychological capital: measurement and relationship with performance and satisfaction. Personnel Psychology, 60(3), 541-572.

Luthans, F., \& Avolio, B.J. (2009). The 'point' of positive organizational behavior. Journal of Organizational Behavior, 30(2), 291-307.

Luthans, F., Avey, J.B., Avolio, B.J., \& Peterson, S.J. (2010). The development and resulting performance impact of positive psychological capital. Human Resource Development Quarterly, 21, 41-67.

Luthans, F., Youssef-Morgan, C.M., \& Avolio, B.J. (2015). Psychological Capital and Beyond. Oxford: Oxford University Press.

Rudolph, C.W., Katz, I.M., Lavigne, K.N., \& Zacher, H. (2017). Job crafting: A meta-analysis of relationships with individual differences, job characteristics, and workout comes. Journal of Vocational Behavior, 102, 112-138.

Schaufeli, W.B., Bakker, A.B., \& Salanova, M. (2006). The measurement of work engagement with a short questionnaire: A cross-national study. Educational and Psychological Measurement, 66, 701-716.

Seligmann, M.P. (1998). Learned Optimism. New York: Pocket Books.

Seligmann, M.E. P, Steen, T.A., Park, N., \& Peterson, C. (2005). Positive psychology progress: Empirical validation of interventions. American Psychologist, 60, 410-421.

Sweetman, D., \& Luthans, F. (2010). The power of positive psychology: Psychological capital and work engagement. In: A.B. Bakker, M.P. Leiter (Eds.), Work Engagement. A Handbook of Essential Theory and Research. New York: Psychology Press, 54-68.

Tierney, P., \& Farmer, S.M. (2002). Creative self-efficacy: Its potential antecedents and relationship to creative performance. Academy of Management Journal, 45(6), 1137-1148.

Tims, M., Bakker, A.B., \& Derks, D. (2012). Development and validation of the job crafting scale. Journal of Vocational Behavior, 80(1),173-186.

Tims, M., Bakker, A.B., \& Derks, D. (2014). Daily job crafting and the self-efficacy - performance relationship. Journal of Managerial Psychology, 29(5), 490-507.

Ventura M., Salanova M., \& Llorens S. (2015). Professional self-efficacy as a predictor of burnout and engagement: The role of challenge and hindrance demands. The Journal of Psychology, 149(3), 277-302.

Walumbwa, F.O., Luthans, F., Avey, J.B., \& Oke, A. (2011). Authentically leading groups: the mediating role of collective psychological capital and trust. Journal of Organizational Behavior, 32(1), 4-24. 
Wojtczuk-Turek, A. (2014). Kapitał psychologiczny pracownika. In: M. Juchnowicz (Ed.), Zarzadzanie kapitatem ludzkim. Procesy, narzędzia, aplikacje. Warszawa: PWE, 65-81.

Wojtczuk-Turek, A., \& Turek, D. (2015). Innovative behaviour in the workplace: The role of HR flexibility, individual flexibility, and psychological capital. The case of Poland. European Journal of Innovation Management, 18(3), 397-419.

Wojtczuk-Turek, A. (2016). Wspieranie produktywności pracowników wiedzy. Rola zarzqdzania zasobami ludzkimi i dopasowania człowiek-organizacja. Warszawa: PWN.

Wojtczuk-Turek, A. (2019). Przemiany w pracy opartej na wiedzy w warunkach gospodarki 4.0 - implikacje dla zarządzania ludźmi w organizacjach. In: A. Wojtczuk-Turek (Ed.), Zarzqdzanie kapitałem ludzkim - wyzwania i trendy. Warszawa: Oficyna Wydawnicza SGH, 251-269.

Youssef, C.M., \& Luthans, F. (2013). Managing Psychological Capital in Organizations: Cognitive, Affective, Conative, and Social Mechanism of Happiness. In: S.A. David, I. Boniwell, A. Conley Ayers (Eds.), The Oxford Handbook of Happiness. Oxford: Oxford University Press, 751-766.

Youssef-Morgan, C., \& Dahms, J. (2017). Developing psychological capital to boostwork performance and well-being. In: R.J. Burke, K.M. Page (Eds.), Research Handbook on Work and Well-Being. Cheltenham: Edward Elgar Publishing, 332-350.

\section{Agnieszka Wojtczuk-Turek}

Associate Professor at the Institute of Human Capital at SGH Warsaw School of Economics. Head of the Institute of Human Capital and Organizational Behaviour Unit. Editor-in-Chief of the Education of Economists and Managers Quarterly. Member of the Academy of Management, Eurasia Business and Economics Society, Polish Association of Organizational Psychology. Her scientific work focuses on the topics of competences, employees' attitudes, organizational behaviours, human capital management and development, person-organization fit, and leadership. e-mail address: awojtc@sgh.waw.pl

ORCID: 0000-0002-5384-4181 